\title{
Eksplorasi Gaya Respons Ekstrem dalam Mengisi Kuesioner
}

\author{
Wahyu Widhiarso ${ }^{1}$ \\ Fakultas Psikologi Universitas Gadjah Mada
}

\begin{abstract}
This study aimed to apply the mixture Rasch Model Analysis techniques to identify the proportion of students who possess extreme response styles when completing the questionnaire. Total 2.981 high school students from 30 cities in 15 provinces were instructed to complete questionnaires measuring self-esteem. Self-Self-Esteem Scale consists of four self-reported sub-scales using Likert's model. Analysis suggest that based on how to respond to the scale, student in this study was grouped into three classes: extreme response style class, normal class, and mixture class. These numbers of class were consistent on all four sub-scales. The proportion of students who consistently gave an extreme response on four sub-scales was 4 percent; 6 percent was on three sub-scale, 13 percent on two sub-scales and 53 percent on one sub-scale. The small percentage of students who responded consistently gave an extreme responses suggest that high-school students appropriately choose an option response that represent their trait.
\end{abstract}

Keywords: questionnaire, extreme response style, students' class

\begin{abstract}
Abstrak. Selama ini individu yang memiliki kecenderungan untuk memberikan respons ekstrem sulit untuk dideteksi karena belum ada teknik analisis yang dapat mewadahi tujuan tersebut. Penelitian ini bertujuan untuk mengaplikasikan teknik analisis Model Rasch Campuran untuk mengidentifikasi proporsi siswa yang memiliki gaya respons ekstrem ketika melengkapi butir dalam kuesioner. Partisipan penelitian adalah siswa sekolah SMA dari 30 kota yang tersebar pada 15 propinsi $(\mathrm{N}=2.981)$. Pengukuran harga diri dilakukan dengan menggunakan 4 sub-skala yang mengukur harga diri. Hasil analisis menunjukkan bahwa berdasarkan cara merespons skala, siswa dalam penelitian ini dapat dikelompokkan menjadi tiga kelas: kelas gaya respons ekstrem, normal dan campuran. Proporsi siswa yang konsisten masuk dalam kelas gaya respons ekstrem pada keempat sub-skala sebesar 4 persen, 6 persen pada tiga sub-skala, 13 persen dua sub-skala dan 53 persen pada satu sub-skala. Kecilnya persentase siswa yang memberikan respons ekstrem secara konsisten menunjukkan bahwa partisipan mampu merefleksikan hasil penilaian dirinya pada opsi-opsi respons kuesioner dengan baik.
\end{abstract}

Kata kunci: kuesioner, gaya respons ekstrem, kelas siswa

\footnotetext{
${ }^{\mathbf{1}}$ Korespondensi mengenai isi artikel ini dapat dilakukan melalui: wahyu_psy@ugm.ac.id
} 
Penelitian dalam bidang pendidikan banyak menggunakan kuesioner teknik pelaporan diri sebagai alat pengambilan data. Dengan menggunakan cara ini partisipan diminta melengkapi sendiri butir pertanyaan atau pernyataan yang disediakan di dalam kuesioner. Kuesioner dipakai dalam banyak penelitian untuk mengukur berbagai atribut siswa, misalnya sikap (Mariyani, 2011), persepsi dan minat (Amiruddin, 2008), hingga gangguan psikologis siswa (Widhiarso \& Retnowati, 2011). Kuesioner adalah seperangkat butir tertulis yang dipakai untuk mengukur konstruk yang telah ditentukan dan melalui prosedur penyusunan tertentu (Oppenheim, 1992). Ada dua manfaat penggunaan kuesioner dalam proses pengukuran (Gonyea, 2005). Pertama, pengukuran objektif dan terstandar menghasilkan hasil yang konsisten, namun memiliki jangkauan yang terbatas. Misalnya tes prestasi dapat mengukur kemampuan siswa lebih akurat, akan tetapi hanya mencakup wilayah kecil dari materi pelajaran. Sebaliknya, meski kuesioner memiliki konsistensi yang lebih rendah akan tetapi jenis-jenis atribut yang dapat diukur lebih luas dan bervariasi. Kedua, kadang teknik pelaporan diri pada seting tertentu menjadi satu satunya teknik yang praktis dalam memberikan beberapa jenis informasi sekaligus. Pengukuran dengan menggunakan kuesioner dinilai lebih cepat dan lebih ekonomis untuk diterapkan daripada tes objektif atau studi observasi.

Meskipun populer dalam kancah penelitian, penggunaan kuesioner memiliki beberapa kelemahan. Salah satu kelemahan penggunaan teknik pelaporan diri ini adalah rentannya terhadap respons yang mengandung eror (respons eror).
Dari faktor partisipan, sumber eror tersebut dapat berupa upaya partisipan untuk memberikan kesan positif (Henry \& Raju, 2006), kurang teliti dalam memahami pernyataan butir (Sudman, 1980) dan cara merespons skala yang kurang lazim, misalnya respons ekstrem. Penelitian menunjukkan bahwa pada pengukuran faktor kepribadian, rata-rata respons ekstrem berada pada kisaran persentase yang cukup besar, yaitu antara 25 hingga 30 persen (Austin, Deary, \& Egan, 2006). Respons eror dapat juga diakibatkan oleh individu yang tidak konsisten dalam mengisi kuesioner karena mengacu pada acuan lain selain yang diarahkan oleh kuesioner (Biderman \& Reddock, 2012).

Dari sisi partisipan ada tiga faktor penyebab munculnya respons eror yang banyak dikaji peneliti, yaitu gaya respons (response style), aturan respons (respons set) dan respons bias (bias response). Gaya respons menjelaskan cara individu menanggapi butir dalam kuesioner dengan pola unik dan cenderung konsisten (Weijters, Geuens, \& Schillewaert, 2008). Keunikan tersebut terlihat dari partisipan yang mengisi kuesioner dengan mengacu pada kriteria lain dibanding dengan isi butir kuesioner (van Herk, Poortinga, \& Verhallen, 2004). Selain gaya respons yang sifatnya relatif stabil, ada juga cara individu dalam merespons yang terkait dengan situasi yang dihadapi, tekanan waktu dan teknik pengukuran yang dipakai. Cara seperti ini dinamakan dengan aturan respons (response set). Terminologi gaya respons dan aturan respons kadang digunakan secara tumpang tindih oleh para peneliti. Dalam tulisan ini, untuk menjelaskan kecenderungan unik individu dalam merespons kuesioner digunakan kata gaya respons. 
Sementara itu perbedaan antara respons bias dan gaya respons adalah respon bias terkait dengan isi butir sementara gaya respons muncul karena hal di luar isi butir. Gaya respon lebih sering muncul karena interaksi individu dengan format kuesioner sedangkan respons bias muncul karena butir isi kuesioner. Misalnya kuesioner yang menggali hal-hal yang sensitif seperti perilaku merokok atau sikap terhadap pergaulan bebas. Salah satu bentuk respons bias adalah kecenderungan individu merespons butir pernyataan dengan mendasarkan diri pada apa yang dianggap patut oleh masyarakat (social desirability). Di sisi lain, bentuk gaya respons yang sering kali muncul adalah kecenderungan menyetujui semua pernyataan yang diberikan (acquiescence) dan respons ekstrem. Respons ekstrem ini dapat berbentuk memilih opsi respons paling ujung (sangat setuju, sangat tidak setuju) maupun opsi respons tengah (netral, ragu-ragu atau tidak tahu) (Harzing et al., 2009).

Penelitian menunjukkan bahwa respons eror menyebabkan informasi yang dihasilkan oleh kuesioner menjadi bias dan mereduksi kualitas properti psikometris kuesioner. Respons individu yang tidak konsisten ketika mengisi kuesioner terbukti melemahkan validitas konvergen dan kriteria kuesioner (Biderman \& Reddock, 2012). Respons eror juga dilaporkan menyebabkan hasil estimasi reliabilitas menjadi overestimasi (Peer \& Gamliel, 2011). Dalam proses estimasi parameter butir melalui pendekatan teori respons butir, cara unik individu dalam merespons kuesioner juga terbukti mempengaruhi hasil estimasi butir (Rennie, 1982). Gaya respon adalah variabel yang mengontaminasi dan memiliki efek yang tidak diinginkan pada keandalan dan validitas tes oleh karena itu efek ini harus dikendalikan atau dieliminasi dari analisis.

Penjelasan di muka menunjukkan bahwa pengambilan data dengan menggunakan kuesioner pada siswa rentan terhadap respons eror yang diakibatkan gaya eror. Beberapa faktor pendukung yang dapat dijelaskan di sini adalah kematangan dimensi kognitif siswa (Meisenberg, Lawless, Lambert, \& Newton, 2006), pengalaman berinteraksi dengan kuesioner, dan karakteristik kepribadian (Knowles \& Nathan, 1997). Kematangan dimensi kognitif berkaitan dengan diperlukannya proses kognitif yang cukup kompleks untuk merespons skala (Meisenberg \& Williams, 2008). Proses memahami kalimat butir pernyataan kuesioner, mengingat pengalaman yang pernah dialami, memberikan penilaian terhadap pengalaman itu hingga memilih opsi yang sesuai dengan penilaian, membutuhkan kematangan kognitif. Siswa yang belum matang secara kognitif akan memandang keputusan secara dikotomis, hitam-putih atau benar-salah sehingga dalam merespons cenderung memilih opsi respons ekstrem. Di sisi lain, keterkaitan gaya respons dengan karakteristik kepribadian terlihat dari sifat partisipan yang teliti, patuh terhadap instruksi dan aturan akan menghasilkan respons yang berbeda dengan partisipan yang gegabah dan tidak mengikuti instruksi.

Penelitian yang mengeksplorasi adanya gaya respons pada siswa belum banyak dilakukan. Hal ini dikarenakan prosedur analisis yang dilakukan cukup rumit dan membutuhkan program analisis mendukung. Dengan adanya perkembangan baru teori psikometri maka analisis untuk mengetahui apakah individu 
memiliki kecenderungan gaya respons tertentu memungkinkan untuk dilakukan (Eid \& Zickar, 2007). Perbedaan individual dalam gaya respons juga dipengaruhi oleh apakah individu merasa terwadahi oleh jumlah opsi respons yang disediakan oleh skala. Ada individu yang lebih merasa penilaian dirinya akan terwadahi oleh penilaian sederhana seperti " $y a$ " dan "tidak" namun ada yang merasa lebih mudah melalui opsi berjenjang. Preferensi individu terhadap jumlah opsi respons ini akan dapat menghasilkan perbedaan struktural yang dapat menurunkan kualitas informasi yang dihasilkan survei. Salah satu teknik analisis yang dapat mengakomodasi kebutuhan tersebut adalah Analisis Rasch Campuran (Mixed Rasch Modeling) yang akan dipakai dalam penelitian ini. Metode analisis ini dipakai oleh Widhiarso (2011) untuk mengeksplorasi pengukuran harga diri dan Widhiarso (2012) untuk mengeksplorasi kecenderungan partisipan penelitian dalam memilih opsi respons tengah (misalnya respons netral).

Gaya respons adalah kecenderungan atau preferensi yang bersifat potensial yang aktualisasinya tergantung pada situasi. Oleh karena itu menelaah gaya

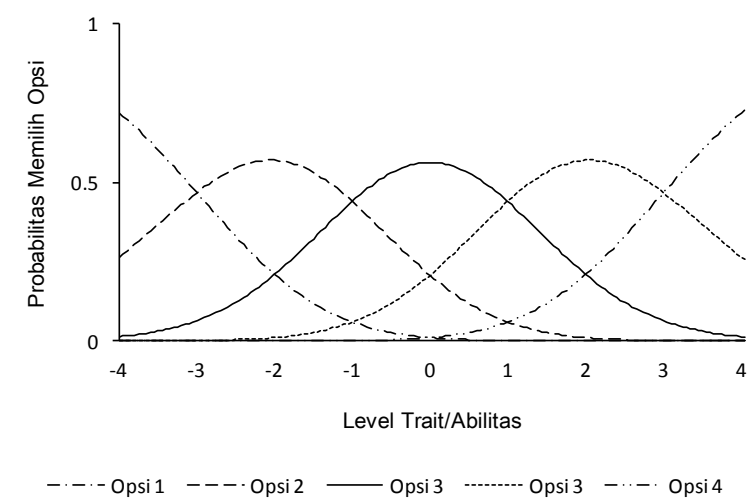

A. Kelompok P (Normal) respons lebih tepat dengan menggunakan pendekatan probabilistik dibanding dengan pendekatan diskriminatif (dilakukan atau tidak). Implikasi penggunaan pendekatan probabilistik ini adalah tiap alternatif yang ada memiliki kemungkinan untuk terjadi. Kemungkinan yang memiliki nilai probabilitas yang besar adalah kemungkinan yang disimpulkan merepresentasikan variabel yang dianalisis. Gambar 1 menjelaskan contoh dua jenis respons kelompok individu (P dan $\mathrm{Q})$ terhadap butir satu butir yang sama dalam kuesioner. Garis di dalam grafik terdiri dari empat jenis sesuai dengan opsi respons dalam kuesioner. Sumbu-X menjelaskan level atribut yang diukur (misalnya harga diri) dari rendah $(<-3)$ hingga tinggi $(>3)$. Sumbu Y menjelaskan probabilitas memilih tiap opsi. Semakin tinggi menunjukkan semakin besar kecenderungan individu untuk memilih opsi respons yang ditawarkan. Kelompok P cenderung memilih opsi respons yang sesuai dengan level harga dirinya. Individu di dalam kelompok $\mathrm{P}$ yang memiliki level harga diri rendah $(<-3)$ cenderung memilih opsi 1 sedangkan yang memiliki level harga diri tinggi (>3) memilih opsi 5. Kasus gaya respons ekstrem ditunjukkan oleh kelompok Q.

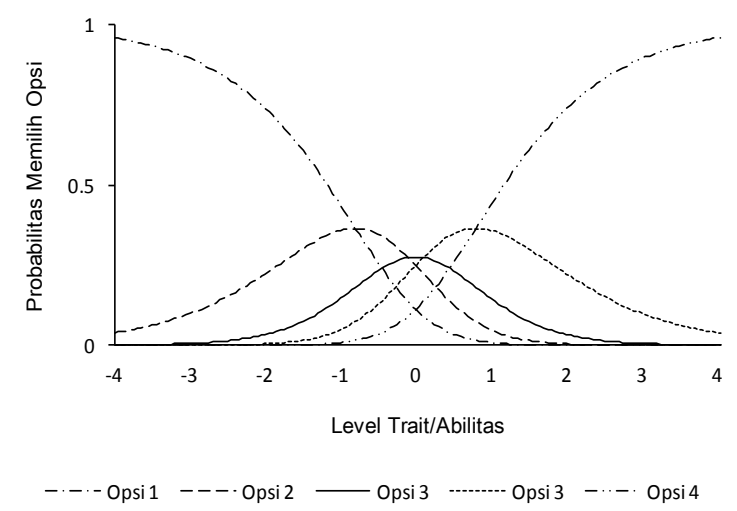

B. Kelompok Q (Ekstrem)

Gambar 1. Perbandingan Dua Jenis Respons Individu 
Karena hanya ada dua opsi respons yang dominan (opsi 1 atau opsi 5) maka hanya ada dua opsi yang cenderung dipilih oleh kelompok ini, yaitu respons ujung.

Mengeksplorasi gaya respons tidak dapat dilakukan dengan melihat berapa persen individu memilih opsi respons ekstrem atau tengah. Ada dua kemungkinan individu memilih opsi tersebut, pertama karena memang opsi tersebut mewakili penilaian terhadap dirinya dan kedua karena individu cenderung memilih respons tersebut secara monoton. Gaya respons baru dapat diidentifikasi ketika parameter butir telah diestimasi kemudian dilanjutkan melihat kesesuaian respons individu terhadap butir. Austin et al. (2006) menjelaskan bahwa perbedaan antar individu dalam merespons kuesioner akan lebih optimal jika dijelaskan dengan model dimensi. Model ini menunjukkan bahwa setiap individu memiliki kriteria sendiri dalam merespons butir kuesioner. Oleh karena itu kelompok individu yang memiliki gaya respons berbeda jika dianalisis secara terpisah akan menghasilkan satu set ambang butir yang berbeda pula. Kelompok individu yang memiliki kesamaan ambang ini dianalisis secara bersama dan dipisahkan dengan kelompok individu lain yang memiliki nilai ambang lainnya. Penelitian yang ditulis di sini mengakomodasi prosedur tersebut melalui pendekatan Analisis Rasch Campuran.

\section{Metode}

\section{Partisipan Penelitian}

Partisipan penelitian adalah siswa kelas XI SMA dari 30 sekolah yang berjumlah 3.000 orang dari 30 kota di Indonesia yang terbagi dalam 15 propinsi.
Propinsi tersebut adalah Banten, Bengkulu, D.I. Yogyakarta, Jawa Tengah, Jawa Timur, Kalimantan Timur, Lampung, Nusa Tenggara Barat, Sulawesi Selatan, dan Sumatera Selatan. Teknik pemilihan sampel yang dipakai adalah tenik purposif (non-acak) dengan mempertimbangkan proporsi lokasi sekolah (urban dan sub urban). Dari jumlah tersebut data dari 2.959 orang dianalisis karena merespons alat ukur yang diberikan secara lengkap. Proporsi jenis kelami partisipan adalah 36 persen laki-laki dan 63 persen perempuan.

Pengambilan data dilakukan pada kelas sesuai dengan yang ditentukan oleh pihak sekolah. Untuk menjamin keakuratan respons yang diberikan partisipan, peneliti mengambil data tanpa bantuan guru kelas yang bersangkutan. Selain itu partisipan diperkenankan untuk tidak memberikan identitas pada kolom nama di dalam skala (anonim). Waktu yang diperlukan untuk merespons semua butir pada skala rata-rata berlangsung 10 hingga 15 menit.

\section{Instrumen Pengukuran}

Harga diri diukur oleh Inventori Harga Diri yang diadaptasi dari Self Esteem Inventory (SEI) (Roberson \& Miller, 1986). SEI adalah skala pelaporan diri yang terdiri dari 25 pernyataan mengukur empat domain harga diri: rumah-keluarga, teman sebaya, sekolah/akademik, dan harga diri umum. Butir pernyataan skala ini disajikan dalam format skala Likert dengan empat kategori respons yaitu dari "sangat tidak setuju" hingga "sangat setuju". Coopersmith (1981) menjelaskan dukungan yang kuat untuk keandalan dan validitas mengukur. Keandalan data umumnya baik, yang bervariasi dalam studi yang berbeda antara 0.80 dan 0.92 . 
Skala ini pada versi Bahasa Indonesia menunjukkan nilai koefisien reliabilitas pengukuran yang kurang lebih setara (Hadjam, Martaniah, Prawitasari, \& Masrun, 2004), yaitu sebesar 0.82. Hasil pengujian data melalui analisis faktor, alat ukur ini mengukur empat faktor. Sesuai dengan persyaratan analisis data dengan model Teori Respons Butir (Ridho, 2007), maka analisis dilakukan pada tiap faktor (sub-skala) secara terpisah.

\section{Analisis Data}

Gaya respons ditunjukkan dengan tingginya probabilitas individu untuk memilih opsi respons tertentu, misalnya opsi respons ujung atau tengah. Probabilitas tersebut diturunkan dari proses estimasi nilai parameter ambang butir (threshold) yang didapatkan dari proses estimasi dari respons-respons individu. Oleh karena di dalam keseluruhan individu ada yang memiliki gaya respons dan tidak, maka proses estimasi nilai parameter butir dilakukan pada kelompok individu (kelas). Pengelompokan ini dibuat berdasarkan pola respons mereka pada butir-butir di kuesioner. Dari penjelasan ini maka prosedur analisis data pada penelitian ini adalah sebagai berikut:

1. Mengidentifikasi jumlah kelas dan mengestimasi parameter butir pada tiap kelas. Pada tahap ini berbagai model dengan jumlah kelas yang berbeda (1 hingga 4 kelas) dipakai untuk memodelkan data. Setiap model akan menghasilkan kriteria informasi yang menunjukkan ketepatan model dengan data. Penelitian ini menggunakan kriteria informasi Krite- ria Informasi dari Akaike (Akaike Information Criterion/AIC) dan Bayesian (Bayesian Information Criterion atau BIC) sebagai dasar untuk menentukan model yang tepat karena kriteria ini mengakomodasi ukuran sampel dan menghindari parameterisasi yang berlebih.

2. Mengidentifikasi profil tiap kelas dan individu yang menjadi anggotanya. Profil kelas menunjukkan individu-individu yang memiliki kesamaan dalam merespons butir kuesioner. Individu yang memiliki gaya respons yang sama akan masuk dalam kelas yang sama.

Data dalam penelitian ini dianalisis dengan Model Rasch Campuran (Mixed Rasch Model) yang merupakan gabungan antara analisis kelas laten dan kalibrasi data dengan menggunakan Model Rasch. Analisis data dilakukan dengan bantuan program WINMIRA (von Davier, 2001).

\section{H a s i 1}

\section{Statistik Deskriptif}

Deskripsi statistik skor pengukuran harga diri dapat dilihat pada Tabel 1. Dari rerata skor terlihat bahwa skor partisipan cenderung mengarah pada kategori sedang dengan variasi skor yang cenderung rendah, yang ditunjukkan oleh deviasi standar tidak menjangkau skor maksimal (skor=26) jika dikalikan dengan 3 (3 SD). Sementara itu bentuk distribusi skor mendekati distribusi normal ideal karena nilai kemiringan dan keruncingan distribusi mendekati nol. 
WIDHIARSO

Tabel 1

Deskripsi Statistik antar Faktor Harga Diri

\begin{tabular}{|c|c|c|c|c|c|c|c|c|c|}
\hline \multirow{2}{*}{ Faktor } & \multirow{2}{*}{$\begin{array}{c}\text { Jumlah } \\
\text { Butir }\end{array}$} & \multirow{2}{*}{ Min } & \multirow{2}{*}{ Maks } & \multirow{2}{*}{ Rerata } & \multirow{2}{*}{ SD } & \multicolumn{2}{|c|}{ Kemiringan } & \multicolumn{2}{|c|}{ Keruncingan } \\
\hline & & & & & & Nilai & SE & Nilai & SE \\
\hline Faktor 1 & 6 & 6 & 24 & 13,42 & 3,13 & $-0,01$ & 0,04 & $-0,25$ & 0,09 \\
\hline Faktor 2 & 8 & 10 & 32 & 21,51 & 3,35 & 0,10 & 0,04 & 0,09 & 0,09 \\
\hline Faktor 3 & 4 & 4 & 17 & 12,12 & 2,66 & $-0,59$ & 0,04 & $-0,12$ & 0,09 \\
\hline Faktor 4 & 7 & 8 & 28 & 21,72 & 3,68 & $-0,49$ & 0,04 & $-0,02$ & 0,09 \\
\hline
\end{tabular}

\section{Identifikasi Jumlah Kelas}

Jumlah kelas yang tepat dengan data ditentukan oleh nilai AIC dan BIC dari proses analisis kelas dari satu kelas hingga

empat kelas. Pada analisis kelas yang menghasilkan nilai AIC dan BIC yang tidak menunjukkan penurunan dalam jumlah besar ditetapkan merepresentasikan jumlah kelas yang sesuai dengan data. Dari hasil analisis didapatkan informasi bahwa jumlah kelas yang tepat untuk data pada masing-masing sub-skala harga diri adalah tiga kelas. Perubahan nilai AIC dan BIC dari tiga kelas menjadi empat kelas relatif setara dengan perubahan dari dua kelas menjadi tiga kelas.

\section{Keanggotaan Individu dalam Kelas}

Tabel 3 menunjukkan persentase individu di dalam tiap kelas serta probabilitas mereka ketika dimasukkan pada kelasnya. Kelas-X pada Sub-Skala 1 Harga Diri berisi 47 persen individu. Dengan pola respons sama mereka juga berpeluang untuk untuk masuk ke dalam kelas lain, namun probabilitasnya hanya kecil. Masuk ke Kelas-XI dengan peluang 0,16 dan masuk ke Kelas-XII dengan peluang 0.08 .

Dari persentase keanggotaan terlihat bahwa antara satu kelas dengan kelas lainnya pada tiap sub-skala memiliki kemiripan. Di sisi lain tingginya probabilitas untuk masuk ke dalam kelas menunjukkan bahwa antara satu kelas dengan kelas lainnya memiliki perbedaan.

Tabel 2

Perbandingan Indeks Ketepatan Model Berdasarkan jumlah kelas

\begin{tabular}{cccccc}
\hline $\begin{array}{c}\text { Sub Skala } \\
\text { Harga Diri }\end{array}$ & $\begin{array}{c}\text { Indeks Ketepatan } \\
\text { Komparatif }\end{array}$ & $\begin{array}{c}\text { Model 1 } \\
\text { Kelas }\end{array}$ & $\begin{array}{c}\text { Model 2 } \\
\text { Kelas }\end{array}$ & $\begin{array}{c}\text { Model 3 } \\
\text { Kelas }\end{array}$ & $\begin{array}{c}\text { Model 4 } \\
\text { Kelas }\end{array}$ \\
\hline Sub-Skala 1 & AIC & 44396.82 & 44102.25 & 44183.48 & 44265.19 \\
& BIC & 44282.83 & 43868.28 & 43829.51 & 43791.25 \\
Sub-Skala 2 & AIC & 55751.45 & 55007.05 & 54939.28 & 54887.23 \\
& BIC & 55901.41 & 55312.96 & 55401.15 & 55505.05 \\
Sub-Skala 3 & AIC & 28201.17 & 28049.04 & 28043.98 & 28030.08 \\
& BIC & 28279.17 & 28211.03 & 28289.97 & 28360.06 \\
Sub-Skala 4 & AIC & 46721.34 & 45961.75 & 45818.34 & 45690.13 \\
& BIC & 46589.37 & 46231.69 & 46226.25 & 46236.00 \\
\hline
\end{tabular}


Tabel 3

Jumlah Kelas dan Probabilitas Keanggotaan

\begin{tabular}{lcccccc}
\hline \multicolumn{1}{c}{$\begin{array}{c}\text { Sub-Skala } \\
\text { Harga Diri }\end{array}$} & Kelas & Anggota $(\%)$ & $\begin{array}{c}\text { Probabilitas } \\
\text { Tertinggi }\end{array}$ & \multicolumn{3}{c}{ Probabilitas Kelas } \\
\cline { 5 - 7 } Sub-Skala 1 & 1 & 0,47 & 0,76 & 0,76 & 0,16 & 0,08 \\
(6 butir) & 2 & 0,36 & 0,68 & 0,18 & 0,68 & 0,14 \\
& 3 & 0,14 & 0,66 & 0,18 & 0,16 & 0,66 \\
Sub-Skala 2 & 1 & 0,43 & 0,75 & 0,75 & 0,12 & 0,14 \\
(8 butir) & 2 & 0,31 & 0,68 & 0,15 & 0,68 & 0,17 \\
& 3 & 0,26 & 0,65 & 0,16 & 0,19 & 0,65 \\
Sub-Skala 3 & 1 & 0,53 & 0,79 & 0,79 & 0,17 & 0,05 \\
(4 butir) & 2 & 0,29 & 0,65 & 0,19 & 0,65 & 0,16 \\
& 3 & 0,18 & 0,75 & 0,09 & 0,16 & 0,75 \\
Sub-Skala 4 & 1 & 0,43 & 0,63 & 0,63 & 0,17 & 0,20 \\
(7 butir) & 2 & 0,31 & 0,63 & 0,17 & 0,63 & 0,20 \\
& 3 & 0,18 & 0,56 & 0,19 & 0,25 & 0,56 \\
\hline
\end{tabular}

\section{Profil setiap Kelas}

Kelas merupakan kumpulan individu yang memiliki kesamaan cara merespons butir dalam kuesioner. Setelah hasil analisis kelas mendapatkan bahwa pada tiap sub-skala terdiri dari tiga kelas maka langkah selanjutnya adalah mengidentifikasi keunikan tiap kelas. Gambar 2 menunjukkan contoh profil tiga kelas pada Sub-Skala 1 Harga Diri butir 1. Dari perbandingan antar profil kelas terlihat bahwa pada individu pada Kelas-1 cenderung memilih opsi paling ujung (kanan dan kiri). Meski level harga diri mereka sedang (dari skor logit setara -1 hingga 1) akan tetapi hanya ada dua yang cenderung dipilih, yaitu opsi respons 1 dan 4.
Sementara itu, partisipan pada dua kelas lainnya (Kelas-X dan Kelas-XI) cenderung memberikan respons yang sesuai dengan model yang ideal. Partisipan yang memilih opsi 1 adalah mereka yang memiliki level harga diri rendah sedangkan yang memilih opsi 4 adalah mereka yang memiliki harga diri tinggi. Perbedaan dua kelas tersebut terletak pada konsistensi individu dalam merespons semua butir di dalam subskala. Individu pada Kelas-3 lebih konsisten dalam merespons butir sedangkan Kelas-XI kurang konsisten. Individu pada Kelas-XI merespons dua butir di dalam sub-skala dengan gaya respons ekstrem. Pada tulisan ini kelas dengan karakteristik sama dinamakan dengan Kelas Campuran. 


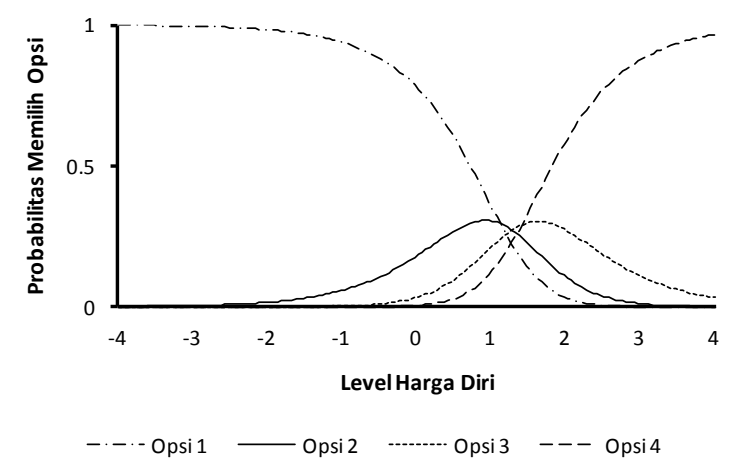

(a) Kelas-1 (Ekstrem)

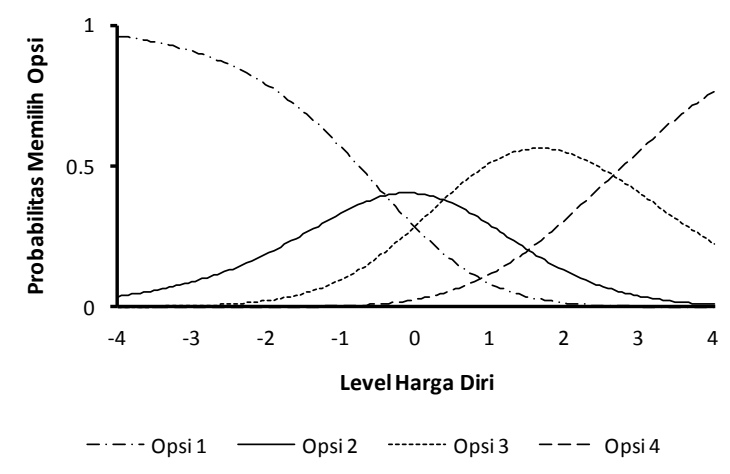

(b) Kelas-2 (Normal)

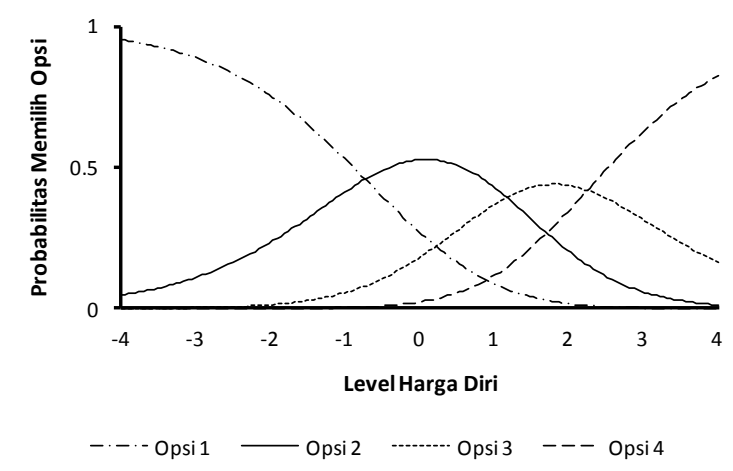

(a) Kelas-3 (Normal)

Gambar 2. Perbandingan Parameter Butir pada Kelas Sub-Skala 1 Harga Diri

Tabel 4

Jumlah Kelas dan Probabilitas Keanggotaan

\begin{tabular}{lccl}
\hline Sub-Skala Harga Diri & Kelas & Persentase & Karakteristik Kelas \\
\hline Sub-Skala 1 & 1 & 0,47 & Gaya respons ekstrem \\
(6 butir) & 2 & 0,36 & Normal \\
& 3 & 0,14 & Campuran \\
Sub-Skala 2 & 1 & 0,43 & Normal \\
(8 butir) & 2 & 0,31 & Campuran \\
& 3 & 0,26 & Gaya respons ekstrem \\
Sub-Skala 3 & 1 & 0,53 & Gaya respons ekstrem \\
(4 butir) & 2 & 0,29 & Normal \\
& 3 & 0,18 & Campuran \\
Sub-Skala 4 & 1 & 0,43 & Normal \\
(7 butir) & 2 & 0,31 & Campuran \\
& 3 & 0,18 & Gaya Respons ekstrem \\
\hline
\end{tabular}


Identifikasi Individu dengan Gaya Respons Ekstrem

Bagian ini akan mengidentifikasi berapa jumlah individu yang konsisten masuk dalam kelas gaya respons ekstrem pada tiap sub-skala. Penghitungan dilakukan pada pasangan sub-skala, dari dua pasang hingga empat pasang. Hasil penghitungan dapat dilihat pada Tabel 5 . Sebagai contoh, partisipan yang terdeteksi konsisten memberikan respons ekstrem pada Skala 1 dan Skala 2 ada 11 persen (N = 329) sedangkan yang terdeteksi konsisten memberikan respons ekstrem pada Skala 1 dan Skala 3 ada 26 persen $(\mathrm{N}=$ 774). Dari hasil penghitungan ini didapatkan ada 4 persen individu yang konsisten masuk dalam kelas gaya respons ekstrem pada keempat sub-skala harga diri. Individu yang konsisten dengan gaya respons ekstrem pada tiga sub-skala berbeda ada 6 persen, dengan persentase antara 4 hingga 8 persen. Sementara itu individu yang konsisten dengan gaya respons ekstrem hanya pada dua sub-skala rata-rata sebesar 13 persen dengan persentase pasangan antara 6 hingga 26 persen.

\section{Diskusi}

Penelitian ini bertujuan mengidentifikasi proporsi siswa di dalam populasi yang memiliki cara merespons butir dengan gaya respons ekstrem. Cara merespons tersebut dilakukan dengan kecenderungan untuk memilih opsi respons paling ujung. Analisis dilakukan pada empat subskala pengukuran harga diri melalui analisis Model Rasch Campuran yang menghasilkan kelompok-kelompok (kelas) siswa. Kelas tersebut ditentukan berdasarkan cara siswa merespons butir-butir kuesioner yang diberikan kepada mereka.

Hasil analisis menunjukkan bahwa keempat sub-skala harga diri menghasilkan tiga kelas yang mewakili karakteristik siswa dalam merespons skala. Setelah profil tiap kelas diidentifikasi, karakteristik tersebut antara lain kelas siswa yang merespons dengan cara normal, campuran dan gaya respons ekstrem. Jumlah siswa yang konsisten masuk ke dalam kelas gaya respons ekstrem pada keempat sub-skala cukup kecil, yaitu 106 siswa (4 persen). Hasil ini berbeda jauh dengan jumlah gaya respons ekstrem yang hanya dihitung pada satu sub-skala saja yang menunjukkan rerata persentase sebesar 36 persen. Rendahnya proporsi siswa yang memiliki gaya respons ekstrem ini menunjukkan bahwa siswa mampu memahami instruksi pengisian kuesioner maupun butir-butir pernyataan yang diberikan. Siswa yang dilibatkan dalam penelitian ini, yaitu siswa SMA, sebagian besar mampu

Tabel 5

Proporsi Individu dengan Gaya Respons Ekstrem

\begin{tabular}{|c|c|c|c|c|c|c|c|c|}
\hline \multirow{2}{*}{2 Pasang } & \multicolumn{2}{|c|}{ Proporsi } & \multirow{2}{*}{3 Pasang } & \multicolumn{2}{|c|}{ Proporsi } & \multirow{2}{*}{4 Pasang } & \multicolumn{2}{|c|}{ Proporsi } \\
\hline & Frek. & $\%$ & & Frek. & $\%$ & & Frek. & $\%$ \\
\hline Skala $1 \& 2$ & 329 & 11 & Skala $1,2 \& 3$ & 229 & 8 & Skala $1,2,3 \& 4$ & 106 & 4 \\
\hline Skala $1 \& 3$ & 774 & 26 & Skala 1, $2 \& 4$ & 125 & 4 & & & \\
\hline Skala $1 \& 4$ & 305 & 10 & Skala $2,3 \& 4$ & 149 & 5 & & & \\
\hline Skala 2 \& 3 & 347 & 12 & Skala $1,3 \& 4$ & 230 & 8 & & & \\
\hline Skala $2 \& 4$ & 186 & 6 & & & & & & \\
\hline Skala $3 \& 4$ & 360 & 12 & & & & & & \\
\hline
\end{tabular}


memilih opsi respons yang tepat untuk mewakili hasil penilaian terhadap dirinya sendiri.

Gaya respons ekstrem yang hanya muncul pada satu sub-skala atau dua subskala saja lebih diakibatkan oleh atribut yang diukur bukan karena karakteristik siswa yang menetap. Sebaliknya gaya respons siswa yang muncul secara konsisten muncul pada keempat sub-skala maka gaya respons ekstrem tersebut melekat pada diri mereka secara menetap. Namun demikian, besarnya persentase siswa pada kelas gaya respons ekstrem untuk analisis satu sub-skala perlu mendapatkan catatan tersendiri. Besarnya persentase dari hasil analisis menunjukkan bahwa antara satu siswa dengan siswa lainnya memaknai butir secara berbeda. Akibatnya, butir-K ("Saya dapat diandalkan") oleh Kelas A mewakili indikator harga diri yang rendah akan tetapi pada Kelas B justru mewakili indikator yang tinggi. Kasus ini terjadi ketika individu pada Kelas A cenderung memilih opsi tertinggi ("sangat setuju") sedangkan individu pada Kelas B cenderung memilih opsi terendah ("sangat tidak setuju"). Hasil tersebut menjadi kontradiktif karena level harga diri individu pada Kelas A dan Kelas B adalah setara.

Kontradiksi dua kelas di atas muncul dalam penelitian ini dan biasanya terjadi karena kontaminasi gaya respons yang berbeda antara kedua kelas. Namun karena dalam penelitian ini didapatkan kesimpulan bahwa gaya respons siswa cenderung rendah maka ada variabel lain yang turut mempengaruhinya. Penulis merekomendasikan agar variabel-variabel ini perlu dieksplorasi lebih lanjut agar kemunculannya dapat dihindari. Dari penjelasan beberapa ahli, variabel-variabel yang dapat dieksplorasi dapat berupa situasi, motivasi, inteligensi dan kecemasan siswa. Penelitian terdahulu menunjukkan bahwa situasi mempengaruhi individu dalam merespons kuesioner (Weijters, Geuens, \& Schillewaert, 2010), motivasi merupakan pendorong individu untuk mengatasi kebosanan dan kelelahan (Krosnick, 1991) dan kecemasan mendorong individu untuk memilih opsi respons moderat dibanding respons ekstrem (Crandall, 1965).

Penelitian ini menemukan bahwa munculnya gaya respons ekstrem tidak terkait dengan jumlah butir dalam kuesioner. Gaya respons ekstrem dengan persentase terbesar terjadi pada sub-skala 3 (4 butir) yaitu sebesar 53 persen. Persentase tidak jauh beda dengan subskala 1 (6 butir) yang menghasilkan gaya respons ekstrem sebesar 47 persen. Hasil penelitian berbeda dengan pernyataan Kieruj dan Moors (2011) yang mengatakan bahwa panjang skala terkait dengan sensitivitas ukur sehingga semakin banyak butir yang dilibatkan, kuesioner lebih sensitif dan dapat mendeteksi gaya respons individu. Penelitian ini tidak menggunakan kuesioner dengan jumlah opsi yang berbeda-beda sehingga hasil penelitian ini masih terbatas pada kuesioner dengan empat opsi respons. Dengan format lain, misalnya format lima respons dimungkinkan gaya respons ekstrem dapat direduksi karena jumlah individu yang memilih opsi respons tengah semakin meningkat. Namun demikian perlu diidentifikasi apakah pemilihan respons tengah tersebut merefleksikan gaya respons yang lain ataukah memang merefleksikan penilaian individu.

Dari sisi alat ukur yang dipakai dalam penelitian ini, adanya kelas-kelas dalam 
sub-skala harga diri menunjukkan bahwa butir di dalamnya direspons secara berbeda-beda oleh siswa. Secara ideal, satu kuesioner mampu mewadahi keragaman individu yang diminta melengkapi. Untuk mencapai hal tersebut dua cara yang dapat dilakukan. Pertama, melibatkan butir yang homogen dan telah diuji melalui pendekatan teori respons butir. Selama ini pemanfaatan teori respons butir untuk pengembangan skala masih kalah dibanding dengan teori skor murni klasik. Kedua, melakukan pemilihan sampel secara acak untuk meminimalisir kontaminasi variabel-variabel ekstra yang dapat meningkatkan respons eror.

Penelitian ini mendemonstrasikan penggunaan teknik analisis Model Rasch Campuran dalam mengidentifikasi gaya respons individu. Teknik ini tergolong baru dan mengatasi beberapa keterbatasan teknik sebelumnya, misalnya standarisasi skor (Fischer, 2004). Teknik standarisasi tidak dapat menjawab apakah individu yang mendapatkan skor tinggi ini disebabkan oleh bias respons ataukah benarbenar mencerminkan pendapat yang kuat tentang atribut yang diukur. Teknik analisis Model Rasch Campuran selain mampu mendeteksi munculnya gaya respons individu juga mampu mendeteksi individu-individu yang memiliki pola respons unik yang menurunkan kualitas properti psikometris kuesioner. Dalam penelitian kuantitatif, ketika dua variabel yang dikorelasikan di dalamnya mengandung banyak respons eror maka nilai korelasi yang dihasilkan cenderung over estimasi karena varians eror dari kedua variabel tumpang tindih. Untuk mengatasi hal ini peneliti dapat mengeluarkan individu dengan karakteristik ini dari analisis.

\section{Kesimpulan}

Penelitian ini menemukan bahwa persentase siswa yang konsisten memiliki gaya respons ekstrem relatif kecil. Partisipan penelitian yang merupakan siswa SMA dapat memahami instruksi pengisian kuesioner dan mampu memilih opsi respons yang tepat untuk mewakili hasil penilaian terhadap dirinya. Munculnya gaya respons ekstrem lebih banyak dikarenakan faktor situasi administrasi pengukuran dan butir kuesioner yang tidak mewadahi keragaman karakteristik siswa. Penelitian ini mendemonstrasikan penggunaan Model Rasch Campuran untuk mengidentifikasi gaya respons siswa. Dari analisis Model Rasch Campuran ditemukan adanya tiga karakteristik siswa dalam merespons butir, yaitu respons normal, campuran dan gaya respons ekstrem. Ketiga jenis respons ini muncul secara konsisten pada tiap subskala yang dipakai dalam penelitian ini. Rekomendasi yang dapat diberikan kepada penulis selanjutnya adalah mengeksplorasi lebih lanjut faktor-faktor yang mempengaruhi munculnya gaya respons ekstrem ini. Secara umum hasil penelitian ini mendukung penggunaan kuesioner untuk mengukur atribut pada siswa dan agar para penyusun kuesioner mempertimbangkan keragaman siswa dalam merespons butir kuesioner.

\section{Kepustakaan}

Amiruddin. (2008). Persepsi Siswa SMP 1 Negeri Sigli terhadap Penghijauan. Jurnal Pendidikan Serambi, 5(2), 62-65.

Austin, E. J., Deary, I. J., \& Egan, V. (2006). Individual differences in response 
scale use: Mixed Rasch modelling of responses to NEO-FFI items. Personality and Individual Differences, 40(6), 1235-1245. http://dx.doi.org/ 10.1016/ j. paid.2005.10.018

Biderman, M. D., \& Reddock, C. M. (2012). The relationship of scale reliability and validity to partisipant inconsistency. Personality and Individual Differences, 52(5), 647-651. http://dx.doi.org/10.10 16/j.paid.2011.12.012

Crandall, J. E. (1965). Some Relationships among Sex, Anxiety, and Conservatism of Judgment. Journal of Personality, 33(1), 99-107. http://dx.doi.org/ 10.1111/j.1467-6494.1965.tb01374.x

Eid, M., \& Zickar, M. J. (2007). Detecting response styles and faking in personality and organizational assessments by mixed Rasch models. In M. Von Davier \& C. Carstensen (Eds.), Multivariate and Mixture Distribution Rasch Models. New York: Springer.

Fischer, R. (2004). Standardization to Account for Cross-Cultural Response Bias. Journal of Cross-Cultural Psychology, 35(3), 263-282. http://dx.doi.org/ $10.1177 / 0022022104264122$

Gonyea, R. M. (2005). Self-reported data in institutional research: Review and recommendations. New Directions for Institutional Research, 127, 73-89. http://dx.doi.org/10.1002/ir.156

Hadjam, M. N. R., Martaniah, S. M., Prawitasari, J. E., \& Masrun. (2004). The role of hardiness in somatization disorders Anima Indonesian Psychological Journal, 19(2), 122-135.

Harzing, A. W., \& 26 Collaborators. (2009). Rating versus ranking: What is the best way to reduce response and language bias in cross-national research? International Business Review, 18(417-432). http://dx.doi.org/ 10.1016/ j.ibusrev. 2009.03.001

Henry, M. S., \& Raju, N. S. (2006). The effects of traited and situational impression management on a personality test: an empirical analysis. Psychology Science, 48(3), 247-267.

Kieruj, N., \& Moors, G. (2011). Response style behavior: question format dependent or personal style? Quality $\mathcal{E}$ Quantity, 1-19. http://dx.doi.org/10. 1007/s11135-011-9511-4

Knowles, E. S., \& Nathan, K. T. (1997). Acquiescent Responding in SelfReports: Cognitive Style or Social Concern? Journal of Research in Personality, 31(2), 293-301. http://dx.doi.org/ 10.1006/ jrpe.1997.2180

Krosnick, J. A. (1991). Response strategies for coping with the cognitive demands of attitude measures in surveys. Applied Cognitive Psychology, 5(3), 213236. http://dx.doi.org/ 10.1002/ acp. 235 0050305

Mariyani, D. (2011). Hubungan antara sikap siswa terhadap pelajaran matematika dengan prestasi belajar matematika pada siswa SMK N. (Skripsi, tidak dipublikasikan), UIN Sunan Kalijaga Yogyakarta, Yogyakarta.

Meisenberg, G., Lawless, E., Lambert, E., \& Newton, A. (2006). The social ecology of intelligence on a Caribbean island. Mankind Quarterly, 46, 395-433.

Meisenberg, G., \& Williams, A. (2008). Are acquiescent and extreme response styles related to low intelligence and education? Personality and Individual Differences, 44(7), 1539-1550. http://dx.doi.org/10.1016/j.paid.2008.01 .010 
Oppenheim, A. N. (1992). Questionnaire design, interviewing and attitude measurement (new ed.). New York, NY: Pinter Publishers.

Peer, E., \& Gamliel, E. (2011). Too reliable to be true? Response bias as a potential source of inflation in paper-and-pencil questionnaire reliability. Practical Assessment, Research $\mathcal{E}$ Evaluation, 16(9), 1-8.

Rennie, L. J. (1982). Research Note: Detecting a response set to Likert-style attitude items with the rating model. Education Research and Perspectives, 9(1), 114-118.

Ridho, A. (2007). Karakteristik psikometrik tes berdasarkan pendekatan teori tes klasik dan teori respon aitem Jurnal Psikologi INSAN, 2(2), 1-27.

Roberson, T. G., \& Miller, E. (1986). The Coopersmith Self-Esteem Inventory: A Factor Analytic Study. Educational and Psychological Measurement, 46(1), 269273.

http://dx.doi.org/10.1177/001316448646 1033

Sudman, S. (1980). Reducing Response Error in Surveys. Journal of the Royal Statistical Society. Series D (The Statistician), 29(4), 237-273. http://dx.doi.org/10.2307/2987730

van Herk, H., Poortinga, Y. H., \& Verhallen, T. M. M. (2004). Response Styles in Rating Scales. Journal of Cross-
Cultural Psychology, 35(3), 346-360. http://dx.doi.org/10.1177/002202210426 4126

von Davier, M. (2001). WINMIRA 2001. Kiel: Institute for Science Education.

Weijters, B., Geuens, M., \& Schillewaert, N. (2008). The stability of individual response styles. Working Paper. Ghent University. Gent.

Weijters, B., Geuens, M., \& Schillewaert, N. (2010). The Individual Consistency of Acquiescence and Extreme Response Style in Self-Report Questionnaires. Applied Psychological Measurement, 34(2), 105-121. http://dx.doi.org/ 10.1177/0146621609338593

Widhiarso, W. (2011). Aplikasi Model Rasch Campuran dalam Mengevaluasi Pengukuran Harga Diri Jurnal Penelitian dan Evaluasi Pendidikan, 17(1), 172-187.

Widhiarso, W. (2012). Aplikasi Teori Respons Butir untuk Mengidentifikasi Kecenderungan Partisipan Memilih Opsi Tengah pada Skala Psikologi. Proyeksi, 7(1), 33-43.

Widhiarso, W., \& Retnowati, S. (2011). Investigasi butir bias jender dalam pengukuran depresi melalui Children's Depression Inventory (CDI). Jurnal Penelitian Psikologi, 2(1), 1-10. 